\title{
CONTROL OF Bipolaris oryzae (Breda de Haan) USING Curcuma longa (Linnaeus) EXTRACT AND EFFECT OF THIS EXTRACT ON RICE SEED PHYSIOLOGY ${ }^{1}$
}

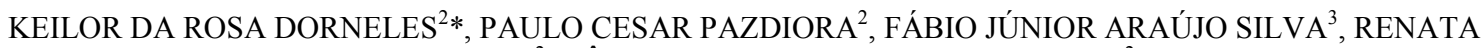 \\ MOCCELLIN $^{2}$, CÂNDIDA RENATA JACOBSEN FARIAS ${ }^{2}$
}

\begin{abstract}
This study was conducted to evaluate the use of Curcuma longa (Linnaeus) extract in the in vitro control of Bipolaris oryzae (Breda de Haan) and to characterize the effect of this extract on rice seed germination. A completely randomized arranged in a factorial experimental design was used: three isolates of $B$. oryzae from rice seed from different rice-growing regions of Rio Grande do Sul (Fronteira Oeste, Campanha, and Sul) were tested with three concentrations $(20,40$, and $80 \mathrm{mg} / \mathrm{mL})$ of C. longa plus a control treatment $(0 \mathrm{mg} / \mathrm{mL})$. Each reaction was repeated in quadruplicate. The effect of the extract upon the disease development was evaluated based on mycelial growth (PMG) and spore production; rice seed germination was evaluated using a germination test (Germitest $\left.{ }^{\circledR}\right)$. The PMG results demonstrate that the treatments were effective in reducing PMG, with a stronger response observed as the concentration of the extract increased. An average inhibition of $84 \%$ of sporulation was observed for the tested strains compared with the control treatment. There were, however, no significant differences in terms of seed germination test with the different C. longa concentrations. Therefore, treatment of rice seeds with $C$. longa extract does not affect seed germination but positively inhibits mycelial growth and sporulation, affecting the in vitro sporulation of the different isolates of $B$. oryzae.
\end{abstract}

Keywords: Curcuma. Alternative control. Brown spot.

\section{CONTROLE IN VITRO DE Bipolaris oryzae (Breda de Haan) COM EXTRATO DE Curcuma longa (Linnaeus) E SUA INTERFERÊNCIA NA FISIOLOGIA DAS SEMENTES DE ARROZ}

\begin{abstract}
RESUMO - Objetivou-se avaliar o uso do extrato de Curcuma longa (Linnaeus) no controle de Bipolaris oryzae (Breda de Haan) in vitro, bem como conhecer o seu efeito sobre a germinação de sementes de arroz. $\mathrm{O}$ delineamento experimental foi inteiramente casualizado arranjado em um sistema fatorial: três isolados de $B$. oryzae de sementes de arroz, oriundas de três regiões orizícolas do Rio Grande do Sul (fronteira oeste; campanha e sul) x três concentrações $(20 ; 40$ e $80 \mathrm{mg} / \mathrm{mL})$ de C. longa, mais um tratamento controle $(0 \mathrm{mg} /$ $\mathrm{mL}$ ), com quatro repetições. O efeito do extrato sobre o desenvolvimento do patógeno foi avaliado a partir do crescimento micelial (CMC) e produção de esporos, para a germinação das sementes de arroz foi avaliado através do teste de germinação em papel toalha (Germitest $\left.{ }^{\circledR}\right)$. Os resultados para o CMC demonstram que os tratamentos foram efetivos, reduzindo o CMC conforme aumentava-se as concentrações do extrato. Em relação a esporulação, ocorreu a inibição média de $84 \%$ para os isolados testados, quando comparado ao tratamento controle. Já para o teste de germinação de sementes, não houve diferença significativa entre as diferentes concentrações. Dessa forma, conclui-se que o extrato de $C$. longa quando em contato com a semente de arroz, não interfere na sua germinação e que age positivamente inibindo o crescimento micelial e afetando a esporulação dos diferentes isolados de B. oryzae in vitro.
\end{abstract}

Palavras-chave: Curcuma. Controle alternativo. Mancha parda.

\footnotetext{
${ }^{*}$ Corresponding author

${ }^{1}$ Received for publication in 10/12/2016; accepted in 03/17/2017.

${ }^{2}$ Crop Protection Department, Universidade Federal de Pelotas, Faculty of Agronomy Eliseu Maciel, Pelotas, RS, Brazil; keilor.rd@hotmail.com, paulo.pazdiora@yahoo.com.br, renata.moccellin@gmail.com,jacobsencandida@gmail.com.

${ }^{3}$ Department of Phytopathology, Universidade Federal Rural de Pernambuco, Recife, PE, Brazil; fabiojr-@hotmail.com.
} 


\section{INTRODUCTION}

Rice brown spot caused by the fungus Bipolaris oryzae (Breda de Haan) (Cochliobolus miyabeanus S. Ito \& Kurib) (SOSBAI, 2016) is one of the main diseases that causes significant crop losses in rice-growing regions worldwide (LUDWIG et al., 2009; SOSBAI, 2016).

The symptoms of brown spot can be observed in several parts of the plant, but it has the greatest effect when present on the leaves, where it reduces the active photosynthetic area, or on the grains, where it affects their quality, and can cause yield losses of up to $72 \%$ (MALAVOLTA et al., 2007). Currently, control of this disease relies on the use of chemicals, as there are few cultivars available with resistance to the pathogen (GROHS et al., 2010). As reported by SOSBAI (2016), fungicides of the triazol group or mixtures of triazols and strobilurins have been reported to be effective for the control of $B$. oryzae. Unfortunately, these agrochemicals increase the production costs of the crop and can have negative impacts on the environment (KAGALE et al., 2004; HARISH et al., 2007).

The use of alternative methods of disease control is becoming more popular to help minimize the negative effects of agrochemicals and facilitate sustainable food production. Many of these methods rely on the use of natural plant extracts and oils that are sources of a wide spectrum of compounds with antimicrobial action that can be utilized in integrated disease management (GURJAR et al., 2012). For example, Cymbopogon citratus and Thymus vulgaris essential oils have been shown to be effective seed treatments for the control of rice seed-spotting fungi (NGUEFACK et al., 2008).

Turmeric (Curcuma longa Linnaeus) is known for its antibacterial and antioxidant pharmacological functions (ARAÚJO; LEON, 2001). The use of $C$. longa root extract proved effective in the in vitro control of phytopathogens such as Colletotrichum gloeosporioides and Fusarium oxysporum Schlecht. (SINGH; SINGH; MAURYA, 2002). When used in vivo, it reduced the severity of early blight (Alternaria solani) in tomato plants under greenhouse conditions (BALBI-PEÑA et al., 2006).

Although Nguefack et al. (2008) found that the natural products of $C$. citratus and $T$. vulgaris were effective in the control of rice grain-affecting fungi, little is known about the effect of those extracts upon the crop. Some volatile compounds produced as plant secondary metabolites are known to have allelopathic or even phytotoxic effects on seeds, preventing them from germinating (ISMAN, 2006). The treatment of corn seeds with different essential oils resulted in a drastic reduction in seed germination, indicating that some oils that are effective treatments against storage fungi may also be negatively affecting seed physiology (BRITO et al., 2012). We, therefore, aimed to evaluate the use of $C$. longa extracts for in vitro control of $B$. oryzae and characterize its effect upon the germination of rice seeds.

\section{MATERIAL AND METHODS}

The experiment was developed in the FAEM/ UFPel Phytopathogenic Fungi and Seed Pathology Laboratory (Laboratório de Patologia de Sementes e Fungos Fitopatogênicos da FAEM/UFPel) - Rio Grande do Sul, Brazil. Isolates of $B$. oryzae obtained from rice seeds collected from three rice-growing regions of Rio Grande do Sul were used; isolate 1 was obtained from Fronteira Oeste (lat. 29 $45^{\prime} 17^{\prime \prime} \mathrm{S}$ and long. $57^{\circ} 05^{\prime} 18^{\prime \prime} \mathrm{W}$ at an altitude of $\left.66 \mathrm{~m}\right)$, isolate 2 from Campanha (lat. $31^{\circ} 19^{\prime} 53^{\prime \prime} \mathrm{S}$ and long. $54^{\circ} 06^{\prime} 25^{\prime \prime} \mathrm{W}$ at an altitude of $212 \mathrm{~m}$ ), and isolate 3 of the South region (lat. $31^{\circ} 46^{\prime} 19^{\prime \prime} \mathrm{S}$, and long. $52^{\circ} 20^{\prime} 33^{\prime \prime} \mathrm{W}$, at an altitude of $17 \mathrm{~m}$ ). Powdered C. longa (Kodilar $\left.{ }^{\circledR}\right)$ was purchased from a local supplier in the Pelotas/RS city.

The effect of $C$. longa on pathogen development was evaluated through mycelial growth and spore production; the effect of the extract on the rice seed germination was also investigated.

The experimental design was completely randomized and was arranged factorially with the three isolates tested against three extract concentrations $(20,40$, and $80 \mathrm{mg} / \mathrm{mL})$ plus one control treatment $(0 \mathrm{mg} / \mathrm{mL})$. Four replicates were included for each treatment.

To evaluate both mycelial growth and sporulation, the fungus was grown on potato dextrose agar (PDA) culture media (Acumedia ${ }^{\circledR}$ ) modified with broth containing different concentrations of $C$. longa to achieve final $C$. longa extract concentrations of $0,20,40$, and $80 \mathrm{mg} / \mathrm{mL}$ PDA. The media with extracts were autoclaved and poured into Petri dishes $(80 \times 15 \mathrm{~mm})$. In the central region of each dish a 5-mm-diameter disk containing fungal mycelium was added; the plates were incubated in a growth chamber at $25^{\circ} \mathrm{C}$ with a 12-hour light photoperiod.

Mycelial growth was evaluated daily by measuring the diameter of the colonies with a digital pachymeter (Digital Vernier Caliper ${ }^{\circledR}$ ); measurements were taken $24 \mathrm{~h}$ after the mycelium disk was placed in the culture medium and continued until the colony in one of the treatments spanned the total diameter of the Petri dish.

The mean mycelial growth of each colony (CMC) and the mycelia growth index (IVCM) were evaluated daily for the first $5 \mathrm{~d}$ after inoculation using the formula $\operatorname{IVCM}=\frac{\Sigma(\mathrm{D}-\mathrm{Da})}{\mathrm{N}}$, where IVCM = mycelial growth index; $\mathrm{D}=$ current average diameter of the colony; $\mathrm{Da}=$ average diameter of the colony on the previous day; $\mathrm{N}=$ number of $\mathrm{d}$ after 
inoculation (POLTRONIERI; AZEVEDO; SILVA, 2013).

To evaluate spore production, the number of spores produced per treatment was determined 10 days after inoculation. The spore suspension was obtained by collecting 10 disks mycelium for each replicate; these were transferred to test tubes containing $10 \mathrm{~mL}$ sterile distilled water and were then vortexed $\left(\right.$ PHOENIX $^{\circledR}$, AP 56) before the number of spores was counted using a Neubauer chamber. The results were analyzed through regression analysis with a decreasing exponential equation, determined using the default parameters in the SigmaPlot 10.0 program.

The effect of $C$. longa extracts upon seed germination was determined using Germitest ${ }^{\circledR}$ paper towels that were sterilized and moistened with sterile distilled water containing different concentrations of powdered $C$. longa extract $(0,20$, 40 , and $80 \mathrm{mg} / \mathrm{mL}$ ) according to the previously described seed analysis method (BRASIL, 2009). Before treatment, the seeds were analyzed for the presence of fungi, particularly $B$. oryzae, using the previously described blotter test (BRASIL, 2009). As a high incidence of storage fungi $(35 \%)$ was detected, the surface of the seeds was sterilized by washing with $1 \%$ sodium hypochlorite for $2 \mathrm{~min}$ followed by three washes with sterile distilled water.

For each treatment, 200 seeds of the IRGA 424 cultivar were divided into four replicates of 50 seeds each. The seeds were soaked for $10 \mathrm{~min}$ in sterile water containing different concentrations of C. longa extract before being germinated in an incubation chamber in the vertical position at $25^{\circ} \mathrm{C}$ with $70 \%$ relative humidity and a 12 -h photoperiod.

Germination rates were evaluated after $14 \mathrm{~d}$ when the percentage of germinated seeds, damaged abnormal seedlings, infected abnormal seedlings, hard seeds, and dead seeds were estimated as previously described by BRASIL (2009). Next, ten seedlings were randomly selected for each replicate from which measurements of both the shoot and the root length were taken using a graduated ruler, obtaining the average length for each in $\mathrm{cm}$. The weight of green plant mass was established using a precision balance

The data in percentages were transformed into arcsine (SANTANA; RANAL, 2004) and submitted to analysis of variance. The means were compared using the Tukey test at a $5 \%$ probability threshold using Assistat 7.6 software.

\section{RESULTS AND DISCUSSION}

Mycelial growth (CMC) was evaluated until the fifth day, at which point the mycelium in the controls had reached the edge of the plates. Figure 1 shows that treatment with $C$. longa extract was effective in reducing $\mathrm{CMC}$, with greater extract concentrations resulting in reduced $\mathrm{CMC}$.

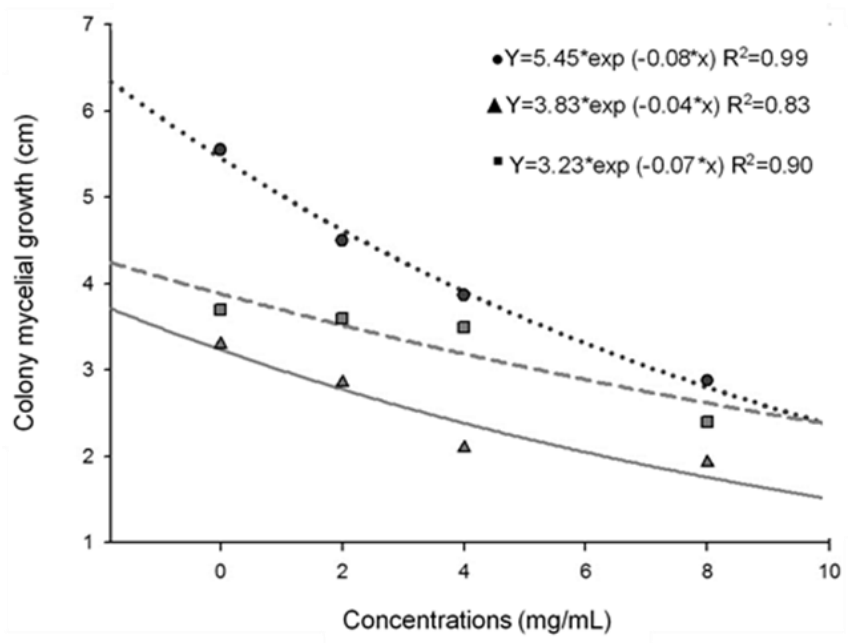

Figure 1. Colony mycelial growth of different isolates of Bipolaris oryzae after 5 days incubation on different concentrations $(0,20,40$, and $80 \mathrm{mg} / \mathrm{mL})$ of Curcuma longa extract in potato dextrose agar. $\bullet$ isolate one, $\boldsymbol{\Delta}$ isolate two, and $\mathbf{m}$ isolate three.

After $5 \mathrm{~d}$ of growth, a reduction in CMC of $40 \%$ to $60 \%$ was observed for the three isolates at the highest concentration of $C$. longa extract $(80 \mathrm{mg} / \mathrm{mL})$. These levels of mycelial growth inhibition were similar to the levels of inhibition observed for $F$. verticillioides when exposed $20 \mu \mathrm{g} / \mathrm{mL}$ of turmeric extract, where mycelial growth of colonies was reduced by $56 \%$ (AVANÇO et al., 2017).

The IVCM was also most affected by the highest concentration of $C$. longa extract, with a similar $40-60 \%$ reduction observed for all three isolates treated with $80 \mathrm{mg} / \mathrm{mL} C$. longa extract (Figure 2). 


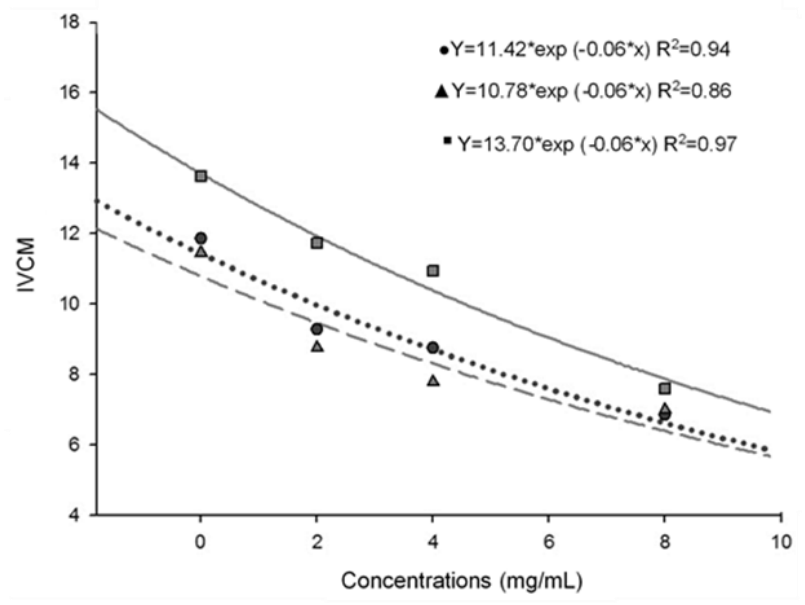

Figure 2. Mycelial growth index (IVCM) of different isolates of Bipolaris oryzae after 5 days incubation on different concentrations $(0,20,40$, and $80 \mathrm{mg} / \mathrm{mL})$ of Curcuma longa extract in potato dextrose agar. $\bullet$ isolate $1, \boldsymbol{\Delta}$ isolate 2 and $\boldsymbol{\bullet}$ isolate 3 .

C. longa extract also affected sporulation, with sporulation in the three isolates decreasing as the extract concentration increased. When treated with $80 \mathrm{mg} / \mathrm{mL} \quad C$. longa extract there was an $82.67 \%, 84.17 \%$, and $83.34 \%$ reduction in sporulation for isolates 1, 2, and 3, respectively, when compared to the control treatment (Figure 3). This suggests that $C$. longa extract has properties that reduce in vitro sporulation of $B$. oryzae at the concentrations tested.

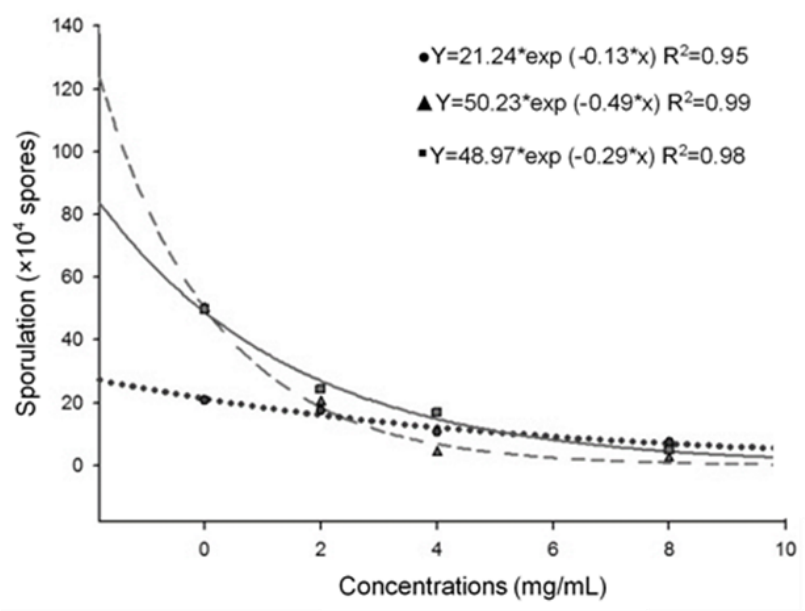

Figure 3. Spore production or sporulation $\left(\times 10^{4}\right.$ spores $)$ of different isolates of Bipolaris oryzae on different concentrations $(0,20,40$, and $80 \mathrm{mg} / \mathrm{mL})$ of Curcuma longa extract in potato dextrose agar, 10 days after mycelium in the control dishes had reached the edge of the dish. $\bullet$ isolate $1, \boldsymbol{\Delta}$ isolate 2 and $\boldsymbol{\square}$ isolate 3.

Similar results were observed in the control of A. solani, where C. longa extracts at a concentration of $20 \%$ inhibited $78.6 \%$ of fungal sporulation (BALBI-PEÑA et al., 2006). Consistent with our results, these authors also showed a reduction in the spore production of $B$. oryzae exposed to different concentrations of $C$. longa. The mechanism by which this extract controls pathogen development may be related to compounds present in the rootstock of $C$. longa; these include curcuminoid phenolics, also known as curcumin, that are fungitoxic to phytopathogens (BALASUBRAMANYAM et al., 2003). Using $C$. longa oil for the control of Cyrtomium falcatum and F. moniliforme, Singh, Singh and Maurya (2002) observed complete inhibition of mycelial growth when a dose of $100 \mathrm{mg} / \mathrm{L}$ was used.

In this study, we have shown that different isolates of the same pathogen may have different responses to the presence of $C$. longa extract. While the $C$. longa treatments were effective against all three isolates, each isolate responded differently in terms of the evaluated variables. B. oryzae has a large number of nuclei in the cells of both the hyphae and the conidia (MCDONALD; LINDE, 2002; SOMAYEH et al., 2015), resulting in variations between isolates in terms of growth, sporulation capacity, colony coloration, and aggressiveness (SOUZA; RIBEIRO; GALLI, 1984; MOTLAGH; ANVARI, 2010). These differences 
were apparent in studies carried out in the 1980s and this high genetic variability may be associated with the inter-isolate differences observed in this study. In studies on the genetic resistance of 49 rice cultivars to eight monosporic isolates of $B$. oryzae, different plant responses to isolates of the same fungus were observed (MALAVOLTA; SOUZA; AMARAL, 1992). In addition to the intrinsic variability of the pathogen, the fact that the isolates used in this study were from different regions with edaphoclimatic characteristics may also have played a role. For example, work conducted by Valim-Labres et al. (1997) with isolates of $B$. sorokiniana from different regions showed that the virulence of the isolates was related to the genetic characteristics of the pathogen, the host genotype, and also to environmental pressure associated with geographic differences such as temperature, air relative humidity, and photoperiod. Taken together, these results reinforce the need for studies that elucidate and effectively demonstrate the factors intrinsic to the pathogen and its interaction with the environment and host that actually influence the virulence of the isolates.

We also examined the germination rates of seeds treated with $C$. longa extracts to determine whether the different doses used to treat the seeds had phytotoxic effects. There were no significant differences between the different concentrations of C. longa across any of the nine variables evaluated (Table 1).

Table 1. Percentage of seeds that germinated (PG), damaged abnormal seedlings (ADP), infected abnormal seedlings (PAI), hard seeds (SD), dead seeds (SM), shoot length (CPA), root length (CR), and green mass (MV) of rice seedlings of the IRGA 424 cultivar, $14 \mathrm{~d}$ after soaking in different concentrations of Curcuma longa extract.

\begin{tabular}{|c|c|c|c|c|c|c|c|c|}
\hline \multirow{2}{*}{$\begin{array}{c}\text { Concentrations } \\
\mathrm{mg} / \mathrm{mL}\end{array}$} & PG & PAD & PAI & SD & SM & CPA & $\mathrm{CR}$ & MV \\
\hline & \multicolumn{5}{|c|}{ 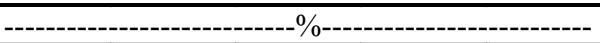 } & \multicolumn{2}{|c|}{------cm----- } & $--g--$ \\
\hline 0 & $24.0 \mathrm{a}$ & $24.2 \mathrm{a}$ & $24.0 \mathrm{a}$ & $19.0 \mathrm{a}$ & $5.0 \mathrm{a}$ & $7.08 \mathrm{a}$ & $3.60 \mathrm{a}$ & $\overline{0.27 \mathrm{a}}$ \\
\hline 20 & $19.5 \mathrm{a}$ & $20.0 \mathrm{a}$ & $26.0 \mathrm{a}$ & $25.0 \mathrm{a}$ & $9.5 \mathrm{a}$ & $6.69 \mathrm{a}$ & $3.13 \mathrm{a}$ & $0.20 \mathrm{a}$ \\
\hline 40 & $23.0 \mathrm{a}$ & $26.0 \mathrm{a}$ & $27.0 \mathrm{a}$ & $17.0 \mathrm{a}$ & $7.0 \mathrm{a}$ & $7.76 \mathrm{a}$ & $3.39 \mathrm{a}$ & $0.27 \mathrm{a}$ \\
\hline 80 & $26.0 \mathrm{a}$ & $21.5 \mathrm{a}$ & $24.0 \mathrm{a}$ & $21.5 \mathrm{a}$ & $6.5 \mathrm{a}$ & $7.21 \mathrm{a}$ & $4.04 \mathrm{a}$ & $0.30 \mathrm{a}$ \\
\hline $\mathrm{CV} \%$ & 22.0 & 33.9 & 53.87 & 38.76 & 61.45 & 13.40 & 15.17 & 20.57 \\
\hline
\end{tabular}

Means followed by the same letter in each column are not statistically different according to the Tukey test $(P \leq 0.05)$.

From the results (Table 1), seed germination rates were low in all treatments. There was, however, a high incidence of hard seeds that were likely dormant, and a high incidence of infected abnormal seedlings. This suggests that, despite the sterilization of the seeds, many may not have been contaminated with the pathogen under study, B. oryzae, but were instead contaminated with other storage fungi like Aspergillus sp. that can cause seedling abnormality. Lazzari (1997), cited in Guimarães et al. (2010), stresses that the fungal contamination by Aspergillus sp. is, in addition to its negative impact on the nutritional value of rice and public health, also responsible for yield losses.

Notably, no $C$. longa treatment at any dose tested resulted in any deleterious physiological effect, relative to the control (Table 1). Given that the main form of dissemination of the fungus is through seeds, this suggests that the treatment of seeds with $C$. longa extracts may be a promising method of controlling the $B$. oryzae pathogen.

Previous works examining the use of extracts and oils for the control of pathogens focused only on the pathogen and not on the effect of these treatments on the plant itself. Given that many plant extracts are known to trigger phytotoxicity in the plant, as was shown by the work of Brito et al. (2012) that identified a reduction in the germination of maize seeds treated with citronella and eucalyptus essential oils, this is an area of significant interest.
The work presented here is, therefore, a fairly novel resource where both the effect of the extract on the pathogen but also on the seed has been evaluated; this work will provide a basis for further studies examining the treatment of rice seeds with $C$. longa extract to control B. oryzae.

\section{CONCLUSIONS}

Extracts of $C$. longa effectively reduced mycelial growth of $B$. oryzae isolates at a range of concentrations, assessed through reductions in the mycelial growth index. This extract also inhibits spore production of $B$. oryzae isolates without interfering with the germination of rice seeds previously soaked in the extract.

\section{REFERENCES}

ARAÚJO, C. A. C.; LEON, L. L. Biological activities of Curcuma longa L. Memórias do Instituto Oswaldo Cruz, Rio de Janeiro, v. 96, n. 5, p. 723-728, 2001.

AVANÇO, G. B. et al. Curcuma longa L. essential oil composition, antioxidant effect, and effect on Fusarium verticillioides and fumonisin production, 
Food Control, United Kingdom, v. 73, n. 5, p. 806813, 2017.

BALASUBRAMANYAM, $M$. et al. Curcumininduced inhibition of cellular reactive oxygen species generation: novel therapeutic implications. Journal of Biosciences, Bangalore, v. 28, n. 6, p. 715-721, 2003.

BALBI-PEÑA, M. I. et al. Controle de Alternaria solani em tomateiro por extratos de Curcuma longa e curcumina - I. avaliação in vitro. Fitopatologia Brasileira, Brasília, v. 31, n. 3, p. 310-314, 2006.

BRASIL. Ministério da Agricultura, Pecuária e Abastecimento. Regras para análise de sementes. Brasília: MAPA/SNPC, 2009. 399 p.

BRITO, D. R. et al. Efeito dos óleos de citronela, eucalipto e composto citronelal sobre micoflora e desenvolvimento de plantas de milho. Journal of Biotechnology and Biodiversity, Gurupi, v. 3, n. 4, p. 184-192, 2012.

GURJAR, M. S. et al. Efficacy of plant extracts in plant disease management. Agricultural Sciences, Toronto, v. 3, n. 3, p. 425-433, 2012.

GROHS, D. S. et al. Critérios para o manejo de doenças no arroz irrigado. Cachoeirinha: IRGA, 2010. 36 p. (Boletim Técnico, nº 7).

GUIMARÃES, I. C. O. et al. Identificação de Aspergillus spp. toxigênico em arroz. Ciência e Tecnologia de Alimentos, Campinas, v. 30, n. 1, p. 60-62, 2010.

HARISH, S. et al. Use of plant extracts and biocontrol agents for the management of brown spot disease in rice. BioControl, Dordrecht, v. 53, n. 3, p. 555-567, 2007.

ISMAN, M. B. Botanical insecticides, deterrents, and repellents in modern agriculture and an increasingly regulated world. Annual Review of Entomology, Palo Alto, v. 51, n. 1, p. 45-66, 2006.

KAGALE, S. et al. Antimicrobial activity and induction of systemic resistance in rice by leaf extract of Datura metel against Rhizoctonia solani and Xanthomonas oryzae pv. oryzae. Physiological and Molecular Plant Pathology, London, v. 65, n. 2, p. 91-100, 2004.

LAZZARI, F. A. Umidade, fungos e micotoxinas na qualidade de sementes, grãos e rações. 2. ed. Curitiba, PR: Ed. do Autor, 1997. 148 p.

LUDWIG, J. et al. Microbiolização de sementes para o controle da mancha-parda e da escaldadura em arroz irrigado. Tropical Plant Pathology, Lavras, v. 34 , n. 5, p. 322-328, 2009.

MALAVOLTA, V. M. A.; SOUZA, T. M. W.; AMARAL, R. E. M. Avaliação de reações foliares de cultivares/linhagens de arroz à mancha-parda (Bipolaris oryzae). Summa Phytopathologica, Botucatu, v. 18, n. 2, p. 118-124, 1992.

MALAVOLTA, V. M. A. et al. Incidência de fungos e quantificação de danos em sementes de genótipos de arroz. Summa Phytopathologica, Botucatu, v. 33, n. 3, p. 280-286, 2007.

MCDONALD, B. A.; LINDE, C. Pathogen population genetics, evolutionary potential, and durable resistance. Annual Review of Phytopathology, Palo Alto, v. 40, n. 2, p. 349-379, 2002.

MOTLAGH, M. R. S.; ANVARI, M. Genetic variation in a population of Bipolaris oryzae based on RAPD-PCR in north of Iran. African Journal of Biotechnology, Ebene, v. 9, n. 36, p. 5800-5804, 2010

NGUEFACK, J. et al. Use of three essential oils as seed treatments against seed-borne fungi of rice (Oryza sativa L.). American-Eurasian. Journal of Agricultural and Environmental Science, New work, v. 4, n. 5, p. 554-560, 2008.

POLTRONIERI, T. P. S.; AZEVEDO, L. A. S.; SILVA, D. E. M. Efeito da temperatura no crescimento micelial, produção e germinação de conídios de Colletotrichum gloeosporioides, isolados de frutos de palmeira juçara (Euterpe edulis Mart). Summa Phytopathologica, Botucatu, v. 39, n. 4, p. 281-285, 2013

SANTANA, D. G.; RANAL, M. A. Análise da germinação - um enfoque estatístico. 1. ed. Brasília, DF: Universidade de Brasília, 2004. 248 p.

SINGH, G.; SINGH, O. P.; MAURYA, S. Chemical and biocidal investigations on essential oils of some Indian Curcuma species. Progress in Crystal Growth and Characterization of Materials, Rio de Janeiro, v. 45, n. 3, p. 75-81. 2002.

SOMAYEH, N. et al. Bipolaris species associated with rice plant: pathogenicity and genetic diversity of Bipolaris oryzae using rep-PCR in Mazandaran province of Iran. Journal of Crop Protection, Tehran, v. 4, n. 4, p. 497-508, 2015.

SOSBAI. Arroz irrigado: recomendações técnicas da pesquisa para o Sul do Brasil. 16. ed. Pelotas, RS: SOSBAI, 2016. 200 p. 
SOUZA, N. R. G.; RIBEIRO, A. S.; GALLI, J. Variabilidade do fungo Helminthosporium oryzae.

Pesquisa Agropecuária Brasileira, Brasília, v. 19, n. 11, p. 1335-1343, 1984.

VALIM-LABRES, M. E. et al. Variação no aspecto cultural, morfologia e virulência em isolados de Bipolaris sorokiniana de trigo. Fitopatologia Brasileira, Brasília, v. 22, n. 4, p. 483, 1997. 